Joanna Kuźmicka-Sulikowska, Dr. hab.

Faculty of Law, Administration and Economics University of Wroclaw, Poland

\title{
TRANSFORMATION OF LEGAL REGULATIONS REGARDING LIMITATION PERIODS OF CLAIMS AND EFFECTS OF THEIR EXPIRATION IN POLISH CIVIL LAW
}

\section{PRASĪBU NOILGUMA TERMIN̦US REGULĒJOŠO LIKUMA NORMU PĀRVEIDOŠANA UN PRASĪBU TERMIN̦U IZBEIGŠANĀS SEKAS POLIJAS CIVILTIESİBĀS}

\begin{abstract}
Kopsavilkums
Rakstā apskatīta Polijas Civilkodeksa attīstība, īpaši pievēršoties sadalıai, kas reglamentē prasību noilguma sekas, un skatot attiecīgo izmainu pamatojumu. İpaša uzmaniba veltita jaunākajiem Civilkodeksa grozījumiem, kas stājušies spēkā ar 2018. gada 13. aprịla likumu. Te uzskaitītas atsevišķas jomas, kuras ietekmē veiktie grozijjumi, kā arī raksturotas praktiskās sekas, kuras grozījumi radījuši šajās jomās. Autore akcentē dažu grozījumu pretrunigo raksturu.

Atslēgvārdi: noilgums, noilguma termiņi, noilguma terminu ex officio apsvērumi, noilgums kā aizstāvỉba, grozijumi tiesību aktos par noilguma terminiem

Summary

This article traces the evolution of Polish Civil Code's framework governing the consequences of expiration of limitation periods of claims, discussing the rationale behind each change. Much attention is given in particular to the latest modifications with the Act of 13 April 2018 Amending the Civil Code, for which a rundown of select areas affected by the amendment is shown along with the practical consequences the amendment brings to such areas. The article does not shirk away from confronting the controversial nature of some of the changes or indeed criticizing some of them.
\end{abstract}

Keywords: statute of limitations, limitation periods, ex officio consideration of limitation periods, limitation as an affirmative defence, legislative amendments concerning limitation periods 


\section{Introduction: overview of legislative transformations concerning the effects of expiration of limitation periods on claims in recent years}

In its original wording, Polish Civil Code, in force since 1 January $1965^{1}$, required courts of law to consider the expiration of limitations periods for economic claims ex officio ${ }^{2}$. Such a legal framework operated smoothly for many years, and only in legal literature there was a discussion of the advantages and disadvantages of the two competitive solutions that could be imagined in this area, i.e. whether it was better for the expiration of limitation periods to be considered ex officio or perhaps it could be more appropriate for limitation to function as an affirmative defence to be raised by the respondent. The discussion gained momentum only on the wave of constitutional changes in Poland in 1989, the effect of which on the legal sphere was a drive to eliminate from Poland's legal order any solutions modelled on Soviet law. The trend saw the just-described solution consisting in ex officio consideration of the expiration of limitation periods - regarded as one of such accretions from Soviet law - was qualified as necessary to be removed from the Polish Civil Code, ${ }^{3}$ which duly happened with Article 1(17) of the Act of 28 July 1990 Amending the Civil Code ${ }^{4}$. In a sort of natural way the solution was replaced with its polar opposite, allowing the courts to consider the lapse of the limitation period only in response to the appropriate affirmative defence having been raised by the respondent. Legal literature of the time stressed that this was adopting the solution already in place in Western European countries ${ }^{5}$.

As it soon turned out, the amendment was not welcomed with approval by majority of Polish society. The reason was primarily that respondents often lacked sufficient familiarity with the legal framework to be able to determine either the timing of the limitation of the claim pursued against them, or when the period of limitation began its course, or whether it had been interrupted or suspended in the meantime or subjected to some other event affecting the way of calculation of the period of limitation of this particular claim. Those in receipt of professional legal advice or suitably well-versed in the law themselves were better prepared to deal with such intricacies. As a result, the mechanisms governing limitations on claims and the consequences of

Act of 23 April 1964 - Civil Code (unified text: Dz.U.2019, pos.1145, as amended), hereinafter also as 'CC'.

2 More broadly see: Broniewicz W. Przedawnienie roszczeń w stosunkach między jednostkami gospodarki uspołecznionej według kodeksu cywilnego (Limitations of claims in relationships between socialized economic entities under the Civil Code). Przegląd Ustawodawstwa Gospodarczego, No. 3, 1965 , p. 61.

3 a tendency then emerged to regard any such Soviet influence as a pathology in need of urgent removal (E. Charkiewicz. Od komunizmu do neoliberalizmu. Technologie transformacji (From communism to neo-liberalism. Technologies of transformation). In: E. Majewska, J. Sowa (eds.). Zniewolony umysł 2. Neoliberalizm i jego krytyki (An enslaved mind 2. Neo-liberalism and its practices), Cracow: Wydawnictwa ha!art, 2007, p. 61, pp. 23-84).

4 Dz.U. No. 55, pos. 321. The Act came into force on 1 October 1990.

5 Brzozowski A. Nowa regulacja przedawnienia w prawie cywilnym (New regulation of limitations in civil law), Państwo i Prawo, No. 3, 1992, pp. 25-26; Wójcik S. Przedawnienie w prawie cywilnym po zmianie kodeksu cywilnego ustawą z 28 lipca 1990 r. (Limitations in civil law following the Civil Code amendment with the Act of 28 July 1990), Przegląd Sądowy, No. 1-2, 1991, p. 48. 
expiration of limitation periods began to be perceived as bestowing a privileged position on those having the benefit of more education or more wealth, thanks to which they could afford professional legal services. The mood intensified especially because of the functioning of the special electronic proceedings by writ of payment ${ }^{6}$ introduced to Polish Code of Civil Procedure 7 . For the practice of the latter led to some unwelcome phenomenon, i.e. professional firms whose entire business objective was buying claims from creditors to enforce them against debtors began the ruthless exploitation of the dominance over the debtors (legal knowledge and financial means), filing e-actions to enforce prescribed claims and, among other tactics they used, intentionally misstating the debtor's address, with the consequence being that the court's writ of payment was not ultimately served on the debtor (who was therefore in no position to raise any defences, such as the expiration of the limitation period of claim) and the time window for challenging the writ also lapsed ${ }^{8}$, as a result of which the surprised debtor first learned of the action during the foreclosure that followed, often at the start of enforcement proceedings against him. This practice was widely assessed in the society and mass media as striking at the weakest, who did not know the law or were deprived of the opportunity to act in court in the above-described way. In response, the legislature, on 10 May 2013, passed an amendment to the Code of Civil Procedure', aiming to cure this situation. Among other changes, claimants were required to provide the respondent's detailed identification (such as the PESEL statistical number or the NIP tax number of a respondent being a natural person - Article $505^{32}(2)(1)$ of the Code of Civil Procedure) and the e-lawsuit remained permitted only for claims maturing within three years prior to filing the action (Article $505^{29 \mathrm{a}}$ of the Code of Civil Procedure). The foregoing was perceived as a legislative intervention aimed to exclude prescribed claims from the e-procedure ${ }^{10}$. Some improvement followed but not a complete success, if only because some claims have a different length of period of limitations, shorter than 3 years (for example, the claims under a sale within the scope of the seller's enterprise have a 2-year period of limitation for claims), hence, they are already prescribed, even though they meet the requirement of the maturity date falling within the three years prior to filing the action. Moreover, it must be noted that the aforementioned legislative intervention of 2013 applied only to electronic proceedings

6 The legal framework for that procedural track was introduced with 1 January 2010 under the Act of 9 January 2009 Amending the Code of Civil Procedure and Some Other Acts (Dz.U. No. 26, pos. 156, as amended).

7 Polish statute regulating court proceedings in broadly understood civil law - the Act of 17 November 1964 - Code of Civil Procedure (unified text: Dz.U.2019, pos. 1460, as amended).

8 Potejko P. Elektroniczne postępowanie upominawcze - fikcja wymiaru sprawiedliwości? (Electronic proceedings by writ of payment - a fiction of justice?), Monitor Prawniczy, No. 1, 2010, p. 16 et seq.

9 This refers to the Act of 10 May 2013 Amending the Code of Civil Procedure (Dz.U. 2013, pos. 654), in force from 7 July 2013.

10 See e.g. Flaga-Gieruszyńska K. In: A. Zieliński (ed.). Kodeks postępowania cywilnego. Komentarz (The Code of Civil Procedure. Commentary). Warsaw: Wydawnictwo C. H. Beck, 2014, p. 986; see also: http://www.infor.pl/prawo/w-sadzie/e-sad/ 320461,Nowelizacja-kodeksu-postepowaniacywilnego-zmiany-w-EPU.html [last viewed April 23, 2019] and http://vislegis.biz/dochodzenieroszczen-przedawnionych-w-epu/ [last viewed April 23, 2019]. 
by writ of payment, hence, it could offer no solution to problems involving claims prescribed on all the other proceedings, including the general proceedings.

In the connection with above, attempting a more general reaction to the aboveoutlined negative societal perception' of requiring the courts to consider the expiration of limitation period for claims only when a defence is specifically raised by respondents, the legislature adopted the Act of 13 April 2018 Amending the Civil Code and Some Other Acts ${ }^{11}$, which entered into force on 9 July 2018. The article will proceeed to assess select aspects of the 13 April 2018 amendment of statutes of limitations and its impact.

\section{Ex officio consideration of the expiration of limitation periods for claims against consumers}

Of central importance to these considerations is the part of the amendment barring the enforcement of claims against consumers upon the lapse of the limitation period (Article $117 \$ 2^{1} \mathrm{CC}$ ). The foregoing was universally perceived as requiring the courts (from that point onward) to consider ex officio the expiration of limitation period for a claim pursued against a consumer ${ }^{12}$. Such an interpretation should be accepted, even though it does not follow expressis verbis from the above-cited provision. First and foremost, this interpretation finds support in the categorical language - [literally] "one may not demand the satisfaction of the claim" - especially when read in conjunction with the preceding Article $117 \$ 2 \mathrm{CC}$, which in reference to other claims states that "after the expiry of the limitation period, the one against whom the claim is entitled may evade its satisfaction".

Against this background it cannot escape notice that the legal framework of statutes of limitations in Polish law became much, much more complicated as a result. Starting from the coming into force of the amendment, i.e. from 9 July 2018, in the case of claims pursued before the court by the entrepreneur from the consumer, the court is obliged to take into consideration ex officio that such claim is time-barred (and consequently, dismiss the claim), whereas, as far as all other claims are concerned, it must not be made, but the fact that the limitation period of claim has expired may only be taken by court into account if the respondent has specifically raised the relevant defence. Such a state of law triggers a number of doubts and practical problems. The key among them becomes drawing the line between those cases where the court should consider the expiration of limitation period for claims ex officio and those where this should only be done if the respondent has raised the specific defence. The language

Dz. U. 2018, pos. 1104.

12 Thus, among others, Machnikowski P. Nowelizacja przepisów Kodeksu cywilnego o przedawnieniu roszczeń (Amendment of the Civil Code's provisions on statutes of limitations). Przegląd Sądowy No. 9, 2018, p. 11; J. Pisuliński, Mała reforma przepisów o przedawnieniu (A small reform of statutes of limitations). In: Dańko-Roesler A., Leśniak M., Skory M., Sołtys B. (eds.). Ius est ars boni et aequi. Księga pamiątkowa dedykowana Profesorowi Józefowi Frąckowiakowi (Ius est ars boni et aequi. Memorial book to Professor Józef Frąckowiak), A. Dańko-Roesler, M. Leśniak, M. Skory, B. Sołtys, Wrocław: Stowarzyszenie Notariuszy Rzeczypospolitej Polskiej, 2018, p. 907. 
of the provision requiring ex officio consideration of the expiration of limitation period of claims, that is Article $117(2)^{1} \mathrm{CC}$, is not conducive to such precision, as it mentions only the ban on demanding the satisfaction of claims against consumers, which is not sufficient for precise demarcation of the scope of application of the provision, especially considering that no mention at all is made of what types of claims, or what claimants', are concerned. In attempting to narrow down these issues it appears that attention should be paid primarily to whom the legislature understands to be a consumer, in accordance with the meaning used in Article $117 \$ 2^{1} \mathrm{CC}$. For explanation, authoritative as it is coming in the form of a legal definition, one needs look no further than in Article $22^{1}$ of the same Code, where the legislature states that a consumer is a natural person who enters with an entrepreneur into a transaction that is not directly connected with such a person's business or professional activities. Once this definition is taken into account in the interpretation of Article $117 \$ 2^{1} \mathrm{CC}$, the conclusion can only be that, starting from 9 July 2018, the courts are now required to consider the expiration of limitation period for claims ex officio only in those cases where the claim being pursued against a consumer is one that belongs to an entrepreneur and results from a transaction (contract) made between such two parties. Some authors reach an identical conclusion ${ }^{13}$, noting that, consequently, this solution cannot be applied to claims originating from anything else than a transaction (e.g. tort or unjustified enrichment), although - recognizing the resulting severe restriction of the scope of application of the new ex officio rule - they call for it to be applied, through expansive teleological interpretation, at least also to claims relating to an invalid transaction (e.g. for the return of a benefit not owed) or other claims originating from failed contract formation ${ }^{14}$. Noteworthy is also, however, the emergence of a position according to which the new Article $117 \$ 2^{1} \mathrm{CC}$, which requires the courts to consider ex officio the expiration the limitation period for claims: "applies to any claims of an entrepreneur against a consumer, both from contractual and non-contractual relations (including claims of unjust enrichment and tort)"15. It is, however, impossible to agree with that view in the light of the comments made previously, as the view fails to find support in the language of the statute and especially in the above-cited Article $22^{1} \mathrm{CC}$, which lays down who is to be regarded as a consumer under Polish law.

Another thing is that, whichever interpretation one may choose to follow, the scope of ex officio consideration of the expiration of limitation period for claims is considerably restricted by requiring this to be done only wherever an entrepreneur is pursuing a claim against a consumer. Key here, therefore, is the classification of the relevant entity as either being a consumer or not, which is not a simple task given the highly subjective criterion provided for such classification in Article $22^{1} \mathrm{CC}$, requiring the court in each such case to judge whether the transaction was or was not directly related with the entity's business or professional activities, before deciding on that basis whether the possible expiration of limitation period for claim is to be considered ex officio or not.

13 Thus, among others, D. Bierecki, Nowe regulacje przedawnienia roszczeń (New regulation on the statute of limitations). Rejent 2018, No. 10, p. 14.

14 Machnikowski P. Nowelizacja..., pp. 12-13.

15 Pisuliński J. Mała reforma..., p. 908. 


\section{Shortening the basic period of limitation of claims; preferential treatment of consumers under interim provisions}

The aforementioned Amending Act of 13 April 2018 also brought the shortening of the basic period of limitation of claims from ten to six years ${ }^{16}$. The change came as somewhat of a surprise, considering how the 6-year limitation period is rare in the provisions of Polish civil law, which tends to employ different lengths of limitation periods (1, 2, 3, 5 or 10 years). Adequate rationale for the change was not provided; the explanatory memorandum ${ }^{17}$ mentions arguments commonly cited in legal literature and court decisions to justify the institution of the statute of limitations as such and provide the ratio for the relevant legal provisions (for example the evidentiary problems that arise with the passage of time $)^{18}$, but they are in no way relativized to justify the choice of the final six-year limitation period for claims.

Leaving aside this rather arbitrary choice by the legislature and focusing instead on what is of substance to the subject of the discussion at hand, it should be noted that the change of the length of the basic limitation period forced the legislator to introduce certain intertemporal (interim) solutions. Those already at first glance appear to afford preferential treatment to consumers. According to the general rule, for claims with origin prior to the entry into force of the Act (i.e. before 9 July 2018) and in relation to which, according to the state on this day, their limitation period has not expired the provisions of the Civil Code regarding limitation of claims in the wording given to them by this Act of 13 April 2018 should be applied (as provided by Article 5(1) of the Act). However, if according to the provisions of the Civil Code in the wording given to them by the Act of 13 April 2018, the limitation period will be shorter than it was according to the previous provisions, then the limitation period begins on the day of entry into force of this Act, i.e. 9 July 2018. But, when the limitation period of particular claim which started before the lastmentioned day would have expired sooner under the prior existing rules, however, such a shorter period will be used (as follows from Article 5(2) of the Act of 13 April 2018). In a situation when the relevant claim had prior a ten-year limitation period and from 9 July 2018 onward it has a six-year term, the creditor is entitled to the full six years counting from that day (if less than four years of limitation had passed before that date). This can sometimes be to the creditor's disadvantage, in effect significantly reducing the limitations periods on the creditor's claims, especially if only

16 Or, more accurately, a time span ranging from 6 to almost 7 years, which also follows from the 13 April 2018 Amending Act's new wording of Article 118 sentence 2 CC, making the end of the limitations period fall upon the last day of a calendar year unless the period is shorter than two years. On the other hand, the aforementioned amendment left intact the existing 3-year limitation period for claims on recurring benefits and business claims.

17 The explanatory memorandum was published in Sejm Print 2216 of the Republic of Poland Sejm of the $8^{\text {th }}$ term. Available at http://www.sejm.gov.pl/Sejm8.nsf/druk.xsp?nr=2216 [last viewed April 23, 2019].

18 For a broader treatment of the subject see: Kuźmicka-Sulikowska J. Idea przedawnienia i jej realizacja w polskim kodeksie cywilnym (The concept of the statute of limitations and its implementation in Polish Civil Code), Wrocław: E-Wydawnictwo. Prawnicza i Ekonomiczna Biblioteka Cyfrowa. Wydział Prawa, Administracji i Ekonomii Uniwersytetu Wrocławskiego, 2015, pp. 61-93. 
an insignificant part of the existing 10-year term has elapsed (e.g. several months) by 9 July 2018, as the claim will be subject to a six-year limitation period calculated from the last-mentioned day. As observed earlier on, the consumer's situation under the interim rules is far more favourable. This follows from that the consumer's claims, which the limitation period according to the state at the moment of entry into force of this last Act (i.e. 9 July 2018) has not yet expired and whose limitation periods are defined in art. 118 and art. $125 \$ 1$ of the Civil Code, fall under the provisions of the Civil Code in wording preceding the 13 April 2018 Amendment (as per Article 5(3) of the Act). Hence, in essence, the date of 9 July 2018 falling during the course of limitation period of a consumer's claim against an entrepreneur does not change anything with regard to the length of the limitation period of such a claim and especially not to the consumer's disadvantage (the 10-year limitation period continues to run and is not reduced). Furthermore, under Article 5(4) of the Act of 13 April 2018, prescribed claims available against a consumer (necessarily held by an entrepreneur, as shown above when analysing Article $22^{1} \mathrm{CC}$ ) without the prescription defence having been raised until the coming into force of the Act of 13 April 2018 (i.e. 9 July 2018) are from that day onward subject to the consequences of prescription set forth in the Civil Code in the wording settled by the Act of 13 April 2018. In consequence, starting from 9 July 2018, the expiration of limitation period for a claim being pursued against a consumer by an entrepreneur will be considered by the court ex officio, even though the claim may have originated and its limitation period has expired prior to 9 July 2018 with the debtor having failed to raise the defence. The legislature's choice of use of such a construction raises objections. It is manifestly changing the rules to the entrepreneur's disadvantage, taking the entrepreneur by surprise. Bringing an action before 9 July 2018 against a consumer, the entrepreneur could hope that perhaps the debtor would not realize that the claim was prescribed or that a specific defence had to be raised, in which case the claim could be upheld and the entrepreneur could win the case. By contrast, starting from 9 July 2018 the legislature has ordered the courts to consider prescription $e x$ officio, removing any chance of victorious litigation for the entrepreneur (unless the court exceptionally applies Article $117^{1} \mathrm{CC}$, which is difficult to expect due to the special nature of the provision), what will involve, for example, an entrepreneur's obligation to bear costs of litigation, which he would not initiate if he knew from the beginning that the expiry of the limitation period will be taken into account ex officio.

\section{Impossibility of achieving legal certainty through the statute of limitations}

The above-cited explanatory memorandum to the Act of 13 April 2018 emphasized that the goal of the reduction of the length of limitation period was to achieve stability and certainty in social relations through statutes of limitation. That, however, does not appear to be possible. Firstly, the goal is set too broadly and is impossible to achieve with only the sole instrument of statutes of limitations; the lapse of the limitation period for particular claim is capable only of stabilizing the legal situation 
with regard to a specific claim. Secondly, the length itself of the limitation period is not what determines the feasibility of such an outcome; rather, the legal consequences attached by the legislature to the expiry of the limitation period are decisive. Those, in turn, as provided under the 13 April 2018 amendment, do not appear to be capable of guaranteeing such stabilization. For first of all, the mechanism requiring the courts to consider the expiration of limitation period ex officio is, as discussed above, severely limited in its material and personal scope of application. Furthermore, there is no certainly whether, even if the mechanism can potentially apply, the result will be the dismissal of the prescribed claim. The foregoing is due to the introduction, by the same Act of 13 April 2018, also of a provision empowering the courts to make an exception from the rule. Thus, the court may, under Article $117^{1} \mathrm{CC}$, in exceptional cases, upon weighing the interests of the parties, decline to uphold the expiration of limitation period for a claim against a consumer (and refuse to adjudicate this claim) if convinced to do so by equitable considerations, taking into account especially the length of the limitation period for particular claim and the time elapsed between its expiry and the pursuit of the claim, as well as the nature of the circumstances leading to the creditor's failure to pursue the claim, including any contribution of the debtor's conduct to the delay.

Besides, it can be observed that no certainty whatsoever arises as to the legal effects the court may attach to the lapse of the limitation period for claims other than those pursued by entrepreneurs against consumers. For in respect of such other claims the existing rule has been retained, and the court is still prevented from considering the expiration of limitation period unless the relevant defence has been raised by the respondent. Even if the respondent realizes that the limitation period has expired and raises the defence, there can still be no certainty that the court will dismiss the claim. This is because of Polish courts' practice of finding themselves entitled to judge if the prescription defence is or isn't an abuse of the respondent's personal right in the understanding of Article $5 \mathrm{CC}$. If the court concludes that such abuse is taking place, it will award the claim despite the limitation period has lapsed and the defence has been raised ${ }^{19}$.

\section{Conclusions}

With the amendment of the provisions of Polish Civil Code on statutes of limitations with the Act of 13 April 2018, the legislature accomplished a partial return to the previous solution requiring the courts to consider the expiration of limitation period ex officio. While the solution is doubtless protective of respondents, one can only guess as to the causes why consumers of all parties were selected to become its beneficiaries

19 For a broader discussion of the practice see: Kuźmicka-Sulikowska J. Idea.., pp. 508-538 along with the court decisions cited therein: Kuźmicka-Sulikowska J. Przedmiot przedawnienia, jego terminy i skutki w projekcie Komisji Kodyfikacyjnej Prawa Cywilnego z 2015 roku i ustawie z dnia 13 kwietnia 2018 roku (The objects, lengths and effects of statutes of limitations in the Civil Code Codification Committee's 2015 draft bill and in the Act of 13 April 2018), Kwartalnik Prawa Prywatnego, No. 3, 2018 , p. 576 along with the court decisions cited therein. 
(and afforded such a high degree of preference as is so amply demonstrated especially by the aforementioned interim provisions), even though the amendment's stated purpose was to react to social demand pointing rather toward a need for more general protection of the less educated, less affluent, unable to afford legal services, as has already been said. Moreover, rather than becoming simplified, the legal rules on prescription were needlessly made more complicated. Due to the 2018 amendment's dichotomous split in the regulation of the consequences of the expiration of limitation period - considered by the courts ex officio in entrepreneurs' cases against consumers and only as a specific defence to be raised by the respondent in all other cases - the courts have at each time to determine whether the respondent is a consumer (with all the negative consequences possibly arising from misclassification) and, if so, consider ex officio whether the claim is prescribed or not. Especially the latter is not an easy task, because the 2018 amendment did not change rule, according to which the civil litigation is governed by the adversarial principle, with it being for the parties to offer evidence and for the court itself only as an exception. Consequently, the court will not necessarily be able to establish the objective truth of the matter but only find whatever follows from whatever evidence the parties may have supplied (sometimes provoking objection, especially in the aforementioned electronic proceedings by writ of payment, where, in accordance with Article 505 ${ }^{32}(1)$ of the Code of Civil Procedure, in electronic lawsuit the claimant need only list evidence in support of the claimant's assertions but without submitting them together with the lawsuit, and in effect the court must judge whether the claim at bar is being pursued against a consumer and whether its limitation period has run only on the basis of the claimant's assertions contained in such a statement of claim, which seems improper, without giving the court virtually no possibility to verify these claims and at the same time forcing courts to base their decision on them). The legislature itself does not seem to deal well with the dichotomy introduced by itself in terms of how to take into account the expiration of limitation period. This is evidenced, for example, by Article $187 \$ 1$ point $1^{1}$ of the Code of Civil Procedure (also introduced by the act of 13 April 2018), on the basis of which, those who file lawsuits in all cases for awarding a claim must obligatorily state the maturity date of the claim. Such a requirement is justified only with regard to claims pursued by entrepreneurs against consumers (considering that in this kind of cases prescribed claims cannot be enforced, which the court must consider ex officio) but is completely unjustified for any claims pursued in other personal setups (e.g. by one business party against another), as it upsets the balance of the parties by requiring one of them to disclose in its own statement of claim information that may be disadvantageous to it, bringing the respondent's attention to the claim's maturity date and potentially suggesting outright the expediency of raising the prescription defence. The foregoing is either an omission on the legislators' part or an intentional step to prevent the enforcement of claims after the expiration of their limitation period. If the latter, then that effect could have been more easily achieved by simply requiring the court to consider the expiration of limitation period for claim ex officio for all claims no matter by whom or against whom pursued. That would have simplified the structure and therewith enabled the state of legal certainty to be achieved realistically with regard to specific claims. The solutions adopted at present do not guarantee this and for many reasons, including the limited scope in which the expiration of limitation period for 
claim is to be considered ex officio, as well as the court's option to deny to do so even where claims are pursued by entrepreneurs against consumers (as follows from Article $117^{1} \mathrm{CC}$, discussed above). It is regrettable that the long-awaited amendment of the Civil Code, finally introduced by the Act of 13 April 2018, has turned out to be so fragmentary. The legislature failed to take the opportunity to streamline the whole system of limitation of claims. This includes failure to introduce any of the conceptual changes - such as have been proposed in the literature for a long time - changes in the rules according to which the limitation period for claims is running or allowing the possibility of contractual modification of the length of the limitation period for a given claim. Nor did the legislature consider whether it is necessary to maintain numerous specific lengths of limitation period for claims in the Civil Code and separate legislation, instead only changing the length of basic limitation period for claims, which so often fails to apply precisely because of the multitude of special provisions imposing different lengths of limitation period for specific types of claims. Such different specific lengths of limitation period for claims could have been unified or removed at all, subjecting these claims to this new basic period of limitation of claims. Firstly, this would increase the amendment's practical importance and, secondly, simplify the whole system of limitation period of claims, making it more transparent for transaction parties. It remains an open issue for discussion whether the six-year term selected by the legislature to be the new basic limitation period for claims is adequate, especially considering how market participants in Poland have not so far been accustomed to such length of limitation period.

\section{BIBLIOGRAPHY}

\section{Literature}

1. Bierecki D. Nowe regulacje przedawnienia roszczen (New regulation on the statute of limitations). Rejent, No. 10, 2018.

2. Broniewicz W. Przedawnienie roszczeń w stosunkach między jednostkami gospodarki uspołecznionej według kodeksu cywilnego. Przegląd Ustawodawstwa Gospodarczego, No. 3, 1965.

3. Brzozowski A. Nowa regulacja przedawnienia w prawie cywilnym (New regulation of limitations in civil law). Państwo i Prawo, No. 3, 1992.

4. Charkiewicz E. Od komunizmu do neoliberalizmu. Technologie transformacji. In: E. Majewska, J. Sowa (eds.). Zniewolony umysł 2. Neoliberalizm i jego krytyki. Cracow: Wydawnictwo: ha!art, 2007.

5. Flaga-Gieruszyńska K. In: A. Zieliński (ed., Kodeks postępowania cywilnego. Komentarz (The Code of Civil Procedure. Commentary). Warsaw: Wydawnictwo C. H. Beck, 2014.

6. Kuźmicka-Sulikowska J. Idea przedawnienia i jej realizacja w polskim kodeksie cywilnym (The concept of the statute of limitations and its implementation in Polish Civil Code). Wroclaw: E-Wydawnictwo. Prawnicza i Ekonomiczna Biblioteka Cyfrowa. Wydział Prawa, Administracji i Ekonomii Uniwersytetu Wrocławskiego, 2015.

7. Kuźmicka-Sulikowska J. Przedmiot przedawnienia, jego terminy i skutki w projekcie Komisji Kodyfikacyjnej Prawa Cywilnego z 2015 roku i ustawie z dnia 13 kwietnia 2018 roku (The objects, lengths and effects of statutes of limitations in the Civil Code Codification Committee's 2015 draft bill and in the Act of 13 April 2018). Kwartalnik Prawa Prywatnego, No. 3, 2018. 
8. Machnikowski P. Nowelizacja przepisów Kodeksu cywilnego o przedawnieniu roszczeń (Amendment of the Civil Code's provisions on statutes of limitations). Przegląd Sądowy, No. 9, 2018.

9. Pisuliński J. Mała reforma przepisów o przedawnieniu (A small reform of statutes of limitations). In: A. Dańko-Roesler, M. Leśniak, M. Skory, B. Sołtys (eds.). Ius est ars boni et aequi. Księga pamiątkowa dedykowana Profesorowi Józefowi Frąckowiakowi (Ius est ars boni et aequi. Memorial book to Professor Józef Frąckowiak). Wrocław: Stowarzyszenie Notariuszy Rzeczypospolitej Polskiej, 2018.

10. Potejko P. Elektroniczne postępowanie upominawcze - fikcja wymiaru sprawiedliwości? (Electronic proceedings by writ of payment - a fiction of justice?), Monitor Prawniczy, No. 1, 2010.

11. Wójcik S. Przedawnienie w prawie cywilnym po zmianie kodeksu cywilnego ustawą z 28 lipca 1990 r. (Limitations in civil law following the Civil Code amendment with the Act of 28 July 1990). Przegląd Sądowy No. 1-2, 1991.

\section{Normative acts}

(all available on: www.sejm.gov.pl)

12. Act of 23 April 1964 - Civil Code (unified text: Dz.U.2019, pos. 1145, as amended), also as 'CC';

13. Act of 17 November 1964 - Code of Civil Procedure (unified text: Dz.U. 2019, pos. 1460, as amended);

14. Act of 28 July 1990 Amending the Civil Code (Dz.U. No. 55, pos. 321);

15. Act of 9 January 2009 Amending the Code of Civil Procedure and Some Other Acts (Dz.U. No. 26, pos.156, as amended);

16. Act of 10 May 2013 Amending the Code of Civil Procedure (Dz.U. 2013, pos. 654);

17. Act of 13 April 2018 Amending the Civil Code and Some Other Acts (Dz.U.2018, pos. 1104).

\section{Internet sources}

18. Nowelizacja kodeksu postępowania cywilnego - zmiany w EPU. Available at http://www.infor. $\mathrm{pl} /$ prawo/w-sadzie/e-sad/320461,Nowelizacja-kodeksu-postepowania-cywilnego-zmiany-wEPU.html [last viewed April 23, 2019].

19. Dochodzenie roszczeń przedawnionych w EPU. Available at http://vislegis.biz/dochodzenieroszczen-przedawnionych-w-epu/ [last viewed April 23, 2019].

20. Ustawa z dnia o zmianie ustawy - Kodeks cywilny oraz niektórych innych ustaw. Available at http://www.sejm.gov.pl/Sejm8.nsf/druk.xsp?nr=2216 [last viewed: April 23, 2019]. 